\title{
PENGARUH KARAKTERISTIK IBU BALITA, FAKTOR PEMUDAH DAN PENGUAT TERHADAP PEMBERIAN IMUNISASI DASAR LENGKAP PADA BAYI DI WILAYAH KERJA PUSKESMAS PIJORKOLING KECAMATAN PADANGSIDIMPUAN TENGGARA
}

\author{
Eva Yusnita Nasution ${ }^{1}$, Wiwi Wardani Tanjung ${ }^{2}$ \\ Akademi Kebidanan Darmais Padangsidimpuan ${ }^{1,2}$ \\ e-mail: ${ }^{1}$ evayusnitanasution@gmail.com
}

\begin{abstract}
Immunization is an effort of giving immunity on infants and children by incorporating the vaccine into the body so that the body makes antibodies to prevent certain diseases. The achievement of fully immunized target based on by National data is around 80-90\%, while the achievement of immunization in Padangsidimpuan in 2014 by $47.1 \%$ and in Pijorkoling Health Centre in 2014, BCG immunization was obtained 49.5\%, DPT / HB3 immunization was obtained $27.6 \%$, polio immunization was obtained $32,4 \%$ and measles immunization was obtained 29,3\%. The objective of this study is to determine and analyze the influence of the characteristics of mothers (work and parity), predisposing factors (knowledge and belief) and reinforcing (husband's support and the support of health professionals) to complete basic immunization on infants in subdistrict Puskesmas Pijorkoling Southeast Padangsidimpuan. This type of research used analytic study with cross sectional approach. The population of this study was all mothers who have infants with sampling proportional sampling technique with a total sample of 81 respondents. Data were collected through medical records and interviews used questionnaires. Data was analyzed by univariate, bivariate used Chi-Square test at the 95\% confidence level $(p<0.05)$ and multivariate used logistic regression test. The results showed that the relationship with $p$ value 0.036 and the support of a husband with a $p$ value of 0.001 against the complete basic immunization on infants. In this study, the relationship of parity with $p$ value 0.180 and the support of health professionals with $p$ value 0.377 to complete basic immunization on infants was not found. The influence of knowledge with $p$ value 0.001 and the value of $\operatorname{Exp}(B) 17.523$ and trust with $p$ value 0.044 and the value of $\operatorname{Exp}(B) 4.460$ to complete basic immunization in infants was affected. It is suggested to the workers of Pijorkoling health center to provide counseling persuasion in improving the knowledge and encourage the mothers to give the complete basic immunization on infants. Thus the achievement of immunization target is more increasing.
\end{abstract}

Keywords : Immunization, Characteristics, Predisposing Factors and Reinforcing

\section{ABSTRAK}

Imunisasi merupakan usaha memberikan kekebalan tubuh pada bayi dan anak dengan memasukkan vaksin kedalam tubuh agar tubuh membuat zat anti untuk mencegah penyakit tertentu. Imunisasi dasar lengkap yaitu imunisasi yang diberikan kepada bayi terdiri dari BCG, DPT, HB, polio dan campak. Target pencapaian imunisasi dasar lengkap secara Nasional 80-90\%, sementara pencapaian imunisasi di Kota Padangsidimpuan Tahun 2014 sebesar 47,1\% dan di Wilayah Kerja Puskesmas Pijorkoling Tahun 2014 BCG 49,5\%, DPT/HB 3 $27,6 \%$, polio $32,4 \%$ dan campak $29,3 \%$. Tujuan penelitian untuk menganalisis pengaruh karakteristik ibu balita (pekerjaan dan paritas), faktor pemudah (pengetahuan dan kepercayaan) dan penguat (dukungan suami dan dukungan tenaga kesehatan) terhadap pemberian imunisasi dasar lengkap pada bayi di Wilayah Kerja Puskesmas Pijorkoling Kecamatan Padangsidimpuan Tenggara. Jenis penelitian adalah studi analitik dengan pendekatan cross sectional. Populasi penelitian seluruh ibu yang mempunyai balita dengan tekhnik pengambilan sampel proportional sampling dengan jumlah sampel sebanyak 81 responden. Data dikumpulkan melalui rekam medik dan wawancara dengan menggunakan kuesioner. Data dianalisis secara univariat, bivariat dengan menggunakan uji Chi- Square pada taraf kepercayaan 95\% ( $\mathrm{p}<0,05)$ dan multivariat dengan uji regresi logistik berganda. Hasil penelitian menunjukkan ada hubungan pekerjaan dengan nilai $p$ value 0,036 dan dukungan suami dengan nilai $p$ value 0,001 terhadap pemberian imunisasi dasar lengkap pada bayi. Tidak ada hubungan paritas dengan nilai $\mathrm{p}$ value 0,180 dan dukungan tenaga kesehatan dengan nilai $p$ value 0,377 terhadap pemberian imunisasi dasar lengkap pada bayi. Ada pengaruh pengetahuan dengan nilai $p$ value 0,001 dan nilai $\operatorname{Exp}$ (B) 17,523 dan kepercayaan dengan nilai $p$ value 0,044 dan nilai $\operatorname{Exp}$ (B) 4,460 terhadap pemberian imunisasi dasar lengkap pada bayi. Kepada tenaga kesehatan Puskesmas Pijorkoling agar memberikan penyuluhan yang sifatnya persuasif untuk meningkatkan pengetahuan dan memengaruhi ibu untuk memberikan imunisasi dasar lengkap pada bayi. Sehingga target pencapaian imunisasi semakin meningkat.

Kata Kunci : Imunisasi, Karakteristik, Faktor Pemudah dan Penguat 

Vol. 16 No. 3 September - Desember 2021

\section{PENDAHULUAN}

\section{Latar Belakang (Opsional)}

Perbaikan kualitas manusia di suatu negara dijabarkan secara internasional dalam Millennium Development Goals (MDGs). Salah satu tujuan MDGs adalah menurunkan 2/3 angka kematian anak di bawah usia lima tahun dari tahun 1990 sampai 2015. Pencapaian tujuan MDGs, program imunisasi menduduki peran yang sangat penting dan strategis, karena imunisasi sebagai upaya efektif pencegahan penyakit tertentu. Besar cakupan imunisasi untuk mencapai Universal Child Imunization (UCI) dalam tingkat nasional, propinsi, kabupaten bahkan desa harus mencapai $80-90 \% .^{1}$

Anak-anak di semua negara secara rutin telah mendapat imunisasi untuk mencegah penyakit berbahaya sehingga imunisasi merupakan dasar kesehatan masyarakat. Namun masih banyak negara berkembang yang masih belum dapat mencapai Universal Child Imunization (UCI) karena cakupan imunisasi yang rendah. Sebenarnya apabila UCI dapat dicapai maka kita dapat menyelamatkan tiga juta anak yang meninggal akibat penyakit yang dapat dicegah dengan imunisasi setiap tahun. ${ }^{3}$

Permenkes Nomor 42 tahun 2013 tentang Penyelenggaraan Imunisasi pasal 3 bahwa pemerintah mewajibkan setiap orang melakukan imunisasi dalam rangka melindungi yang bersangkutan dan masyarakat sekitarnya dari penyakit menular tertentu. Pemerintah, keluarga dan orang tua wajib memberikan imunisasi kepada bayi agar terhindar dari penyakit tertentu. ${ }^{5}$

Di dunia ini diperkirakan 87 negara memiliki angka kejadian hepatitis B kronis yang tinggi (80\%). Pada tahun 2013, secara nasional $1,2 \%$ penduduk Indonesia mengidap Hepatitis B sekitar 649.875 jiwa terindikasi hepatitis B. Selanjutnya hepatitis B berpotensi menjadi hepatitis kronis B yang dapat berakibar kanker hati. Di Indonesia virus hepatitis B $2,1 \%$ ditemukan pada ibu hamil, yang akan berisiko tinggi $90 \%$ menular kepada bayi yang akan dilahirkannya, diperkirakan 1,5 juta anak dari kematian balita di Indonesia adalah akibat penyakit yang dapat dicegah dengan imunisasi/PD3I. ${ }^{3}$

Di Indonesia pada tahun 2014, cakupan imunisasi BCG yaitu 94,0\%, campak 94,7\%, polio 94,4\% dan DPT-HB 49,7\%. Rata-rata angka imunisasi di Indonesia hanya $72 \%$. Artinya, angka di beberapa daerah sangat rendah. Ada sekitar 2.400 anak di Indonesia meninggal setiap hari termasuk yang meninggal karena sebab-sebab yang seharusnya dapat dicegah seperti tuberculosis, campak, pertusis, dipteri dan tetanus. ${ }^{6}$

Berdasarkan data Riskesdas ${ }^{7}$, Sumatera Utara mempunyai cakupan imunisasi HB-0 $(63,0)$, BCG $(78,1)$, DPT-HB3 $(63,1)$, campak $(70,1)$ dan polio 4 $(67,5)$. Papua mempunyai cakupan imunisasi terendah untuk semua jenis imunisasi, meliputi HB-0 $(45,7 \%)$, BCG $(59,4 \%)$, DPT-HB 3 (75,6\%), Polio 4 (48,8\%), dan campak (56,8\%). Provinsi DI Yogyakarta mempunyai cakupan imunisasi tertinggi untuk jenis imunisasi dasar HB-0 $(98,4 \%)$, BCG $(98,9 \%)$, DPTHB 3 (95,1\%), dan campak $(98,1 \%)$ sedangkan cakupan imunisasi polio 4 tertinggi di Gorontalo $(95,8 \%)$. Berdasarkan data tersebut masih banyak daerah-daerah di Indonesia yang belum mencapai target imunisasi.

Sumatera Utara merupakan salah satu daerah yang cakupan imunisasi dasarnya rendah. Salah satu daerah di Sumatera Utara yaitu Kota Padangsidimpuan. Data yang diperoleh dari Dinas Kesehatan Kota Padangsidimpuan tahun 2014 menunjukkan cakupan imunisasi HB-0 (8,3\%), BCG $(69,2 \%)$, DPT-HB $3(57,1 \%)$, Polio $4(51,1 \%)$ dan Campak $(55,3 \%)$. Cakupan imunisasi dasar lengkap yaitu sebesar $47,1 \% .^{8}$ Cakupan imunisasi di daerah Kota Padangsidimpuan masih rendah dan masih jauh dari target pencapaian imunisasi. Cakupan imunisasi yang rendah di Kota Padangsidimpuan membuat para tenaga kesehatan bekerja keras untuk mencapai target pencapaian imunisasi yang optimal. Pencapaian imunisasi yang optimal tidak hanya tugas dari tenaga kesehatan tapi dibutuhkan peran ibu dan dukungan suami untuk meningkatkan cakupan imunisasi.

Namun pada kenyataannya program imunisasi dasar lengkap yang telah dilakukan tidak seluruhnya berhasil dan masih banyak lagi bayi atau balita status kelengkapan imunisasinya belum lengkap. Beberapa faktor penghambat pelaksanaan imunisasi menurut hasil penelitian Worang yang berjudul analisis faktorfaktor yang berhubungan dengan perilaku ibu dalam pemberian imunisasi dasar pada bayi balita di Desa Taraitak satu Kecamatan Langowan Utara wilayah kerja Puskesmas Walantakan tahun 2014 menunjukkan ada hubungan antara tingkat pengetahuan, pendidikan dan sikap dengan perilaku ibu dalam pemberian imunisasi dasar. ${ }^{10}$

Kota Padangsidimpuan mempunyai beberapa puskesmas salah satunya yaitu Puskesmas Pijorkoling. Puskesmas ini merupakan daerah yang pencapaian imunisasinya sangat rendah. Data yang diperoleh bahwa di wilayah kerja Puskesmas Pijorkoling terdapat 2 kelurahan dan 11 desa. Data yang diperoleh dari Puskesmes Pijorkoling Kecamatan Padangsidimpuan Tenggara, di tahun 2013 hanya 3 desa yang mencapai target imunisasi secara nasional (UCI). Pada tahun 2014 tidak ada desa/kelurahan yang mencapai target imunisasi secara nasional (UCI). Data ini menunjukkan rendahnya cakupan imunisasi pada daerah wilayah kerja Puskesmas Pijorkoling yang akan mengakibatkan banyak kerugian dari segala aspek, baik pada bayi/balita, keluarga dan negara. Kerugian atau dampak negatif yang akan timbul yaitu menyebarnya penyakit yang dapat dicegah dengan imunisasi.

Target pencapaian imunisasi di wilayah kerja Puskesmas Pijorkoling yaitu: cakupan BCG untuk mencapai UCI $90 \%$, cakupan DPT/HB 3, polio dan campak untuk mencapai UCI $85 \%$. Pada tahun 2014 
pencapaian imunisasi di wilayah kerja Puskesmas Pijorkoling yaitu cakupan BCG 49,5\%, cakupan DPT/HB $327,6 \%$, cakupan polio 32,4 \%, cakupan campak 29,3\%. ${ }^{12}$ Ini menunjukkan cakupan imunisasi di wilayah kerja Puskesmas Pijorkoling sangat rendah dan masih jauh dari target pencapaian imunisasi.

Berdasarkan survei pendahuluan peneliti melakukan wawancara dengan petugas pengelola program imunisasi di Puskesmas Pijorkoling Kecamatan Padangsidimpuan Tenggara. Menurut pengelola program imunisasi pencapaian imunisasi sangat rendah disebabkan oleh pengetahuan ibu kurang tentang imunisasi dasar lengkap, kurangnya kepercayaan tentang manfaat imunisasi, tenaga kesehatan seperti bidan desa yang tidak tinggal di desa membuat peran tenaga kesehatan kurang terhadap pemberian imunisasi.

Hasil wawancara yang telah penulis lakukan kepada 10 ibu balita di wilayah kerja Puskesmas Pijorkoling, beberapa ibu mengatakan bahwa mereka takut mengimunisasi bayinya karena setelah imunisasi anak menjadi demam dan rewel, selain itu mereka juga tidak mengetahui manfaat dilakukan imunisasi karena menurut mereka banyak anak-anak yang tidak diimunisasi tetapi selalu sehat, ada juga mengatakan tidak ingat jadwal imunisasi.

Berdasarkan uraian tersebut, penulis merasa tertarik dan ingin mengetahui lebih mendalam tentang pengaruh karakteristik ibu balita (pekerjaan dan paritas), faktor pemudah (pengetahuan dan kepercayaan) dan penguat (dukungan suami dan dukungan tenaga kesehatan) terhadap pemberian imunisasi dasar lengkap pada bayi di wilayah kerja Puskesmas Pijorkoling Kecamatan Padangsidimpuan Tenggara.

\section{Tujuan Penelitian (Opsional)}

Untuk menngetahui pengaruh karakteristik ibu balita (pekerjaan dan paritas), faktor pemudah (pengetahuan dan kepercayaan) dan penguat (dukungan suami dan dukungan tenaga kesehatan) terhadap pemberian imunisasi dasar lengkap pada bayi.

\section{Hipotesis (Opsional)}

Ada pengaruh karakteristik ibu balita (pekerjaan dan paritas), faktor pemudah (pengetahuan dan kepercayaan) dan penguat (dukungan suami dan dukungan tenaga kesehatan) terhadap pemberian imunisasi dasar lengkap pada bayi.

\section{METODE}

Jenis penelitian yang digunakan adalah studi analitik dengan pendekatan cross sectional (potong lintang) yang bertujuan untuk menganalisis variabel sebab atau risiko dan akibat atau kasus yang terjadi pada objek penelitian diukur dan dikumpulkan secara simultan (bersamaan). ${ }^{21}$

Populasi dalam penelitian ini adalah seluruh ibu Populasi dalam penelitian ini adalah seluruh ibu yang mempunyai balita (12-24 bulan) yang ada di wilayah kerja Puskesmas Pijorkoling Kecamatan Padangsidimpuan Tenggara berjumlah 434 orang. Sampel dalam penelitian ini adalah ibu yang mempunyai balita (12-24 bulan) yang ada di wilayah kerja Puskesmas Pijorkoling Kecamatan Padangsidimpuan Tenggara dengan besar sampel sebanyak 81 orang. Teknik pengambilan sampel dalam penelitian ini menggunakan teknik proportional sampling.

Jenis data pada penelitian ini terdiri dari dua jenis data: data primer dan data skunder. Data primer adalah data yang diperoleh melalui pengumpulan penyebaran kuesioner yang dibuat oleh peneliti. Data sekunder adalah data yang diperoleh dari catatan Puskesmas Pijorkoling Kecamatan Padangsidimpuan Tenggara dan Dinas Kesehatan Kota Padangsidimpuan.

\section{HASIL}

Hasil penelitian dapat dilihat pada tabel berikut:

Tabel 1

Distribusi Responden Menurut Pemberian Imunisasi Dasar Lengkap di Wilayah Kerja Puskesmas Pijorkoling

\begin{tabular}{llcc}
\hline No. & \multicolumn{1}{c}{ Pemberian } & & \\
& $\begin{array}{c}\text { Imunisasi Dasar } \\
\text { Lengkap }\end{array}$ & Jumlah & Persentase (\%) \\
\hline 1. & Tidak Lengkap & 59 & 72,8 \\
2. & Lengkap & 22 & 27,2 \\
& & & 100 \\
\hline
\end{tabular}

Hasil penelitian menunjukkan bahwa responden yang tidak memberikan imunisasi dasar lengkap sebanyak 59 orang $(72,8 \%)$ dan responden yang memberikan imunisasi dasar lengkap sebanyak 22 orang $(27,2 \%)$.

Tabel 2

Hubungan Pekerjaan dengan Pemberian Imunisasi Dasar Lengkap pada Bayi di Wilayah Kerja Puskesmas Pijorkoling

\begin{tabular}{|c|c|c|c|c|c|c|c|}
\hline \multirow{3}{*}{ Pekerjaan } & \multicolumn{4}{|c|}{$\begin{array}{c}\text { Pemberian } \\
\text { Imunisasi Dasar } \\
\text { Lengkap }\end{array}$} & \multirow{2}{*}{\multicolumn{2}{|c|}{ Jumlah }} & \multirow{3}{*}{$\begin{array}{c}\text { Nilai } \\
p\end{array}$} \\
\hline & \multicolumn{2}{|c|}{ Lengkap } & \multicolumn{2}{|c|}{$\begin{array}{c}\text { Tidak } \\
\text { Lengkap }\end{array}$} & & & \\
\hline & $\mathbf{N}$ & $\%$ & $\mathbf{N}$ & $\%$ & $\mathbf{N}$ & $\%$ & \\
\hline Bekerja & 9 & 18,0 & 41 & 82,0 & 50 & 100 & \\
\hline $\begin{array}{l}\text { Tidak } \\
\text { bekerja }\end{array}$ & 13 & 41,9 & 18 & 58,1 & 31 & 100 & $\begin{array}{c}0,03 \\
6\end{array}$ \\
\hline
\end{tabular}

Hasil uji statistik diperoleh nilai $p=0,036$ maka dapat disimpulkan bahwa ada hubungan antara pekerjaan dengan pemberian imunisasi dasar lengkap pada bayi.

Tabel 3 
Hubungan Paritas dengan Pemberian Imunisasi Dasar Lengkap pada Bayi di Wilayah Kerja Puskesmas Pijorkoling

\begin{tabular}{|c|c|c|c|c|c|c|c|}
\hline \multirow{3}{*}{ Paritas } & \multicolumn{4}{|c|}{$\begin{array}{c}\text { Pemberian } \\
\text { Imunisasi Dasar } \\
\text { Lengkap }\end{array}$} & \multirow{2}{*}{\multicolumn{2}{|c|}{ Jumlah }} & \multirow{3}{*}{$\begin{array}{c}\text { Nilai } \\
p\end{array}$} \\
\hline & \multicolumn{2}{|c|}{ Lengkap } & \multicolumn{2}{|c|}{$\begin{array}{c}\text { Tidak } \\
\text { Lengkap }\end{array}$} & & & \\
\hline & $\mathbf{N}$ & $\%$ & $\mathbf{N}$ & $\%$ & $\mathbf{N}$ & $\%$ & \\
\hline 1 anak & 10 & 38,5 & 16 & 61,5 & \multirow[t]{2}{*}{26} & 100 & \multirow{3}{*}{0,180} \\
\hline$>1$ anak & 12 & 21,8 & 43 & 78,2 & & 100 & \\
\hline & & & & & 55 & & \\
\hline
\end{tabular}

Hasil uji statistik diperoleh nilai $p=0,180$ maka dapat disimpulkan bahwa tidak ada hubungan yang bermakna antara paritas dengan pemberian imunisasi dasar lengkap.

Tabel 4

Hubungan Pengetahuan dengan Pemberian Imunisasi

Dasar Lengkap pada Bayi di Wilayah Kerja Puskesmas Pijorkoling

\begin{tabular}{|c|c|c|c|c|c|c|c|}
\hline \multirow{3}{*}{$\begin{array}{c}\text { Penget } \\
\text { ahuan }\end{array}$} & \multicolumn{4}{|c|}{$\begin{array}{c}\text { Pemberian } \\
\text { Imunisasi Dasar Lengkap }\end{array}$} & \multirow{2}{*}{\multicolumn{2}{|c|}{ Total }} & \multirow{3}{*}{$\begin{array}{c}\text { Nilai } \\
p\end{array}$} \\
\hline & \multicolumn{2}{|c|}{ Lengkap } & \multicolumn{2}{|c|}{$\begin{array}{c}\text { Tidak } \\
\text { Lengkap }\end{array}$} & & & \\
\hline & $\mathbf{N}$ & $\%$ & $\mathbf{N}$ & $\%$ & $\mathbf{N}$ & $\%$ & \\
\hline Baik & 17 & 70,8 & 7 & 29,2 & 24 & 100 & \\
\hline Kurang & 5 & 8,8 & 52 & 91,2 & 57 & 100 & 0,001 \\
\hline
\end{tabular}

Hasil uji statistik diperoleh nilai $p=0,001$ maka dapat disimpulkan bahwa ada hubungan yang bermakna antara pengetahuan dengan pemberian imunisasi dasar lengkap pada bayi.

Tabel 5

Hubungan Kepercayaan dengan Pemberian Imunisasi

Dasar Lengkap pada Bayi di Wilayah Kerja Puskesmas Pijorkoling

\begin{tabular}{lccccccc}
\hline & \multicolumn{4}{c}{ Pemberian } \\
Imunisasi DasarLengkap & \multirow{2}{*}{ Total } & \multirow{2}{*}{ Nilai $p$} \\
\cline { 2 - 5 } $\begin{array}{c}\text { Keperc } \\
\text { ayaan }\end{array}$ & Lengkap & \multicolumn{3}{c}{ Tidak Lengkap } & & \\
\cline { 2 - 6 } & $\mathrm{N}$ & $\%$ & $\mathrm{~N}$ & $\%$ & $\mathrm{~N}$ & $\%$ & \\
\hline Baik & 14 & 50,0 & 14 & 50,0 & 28 & 100 & \multirow{2}{*}{0,002} \\
Kurang & 8 & 15,1 & 45 & 84,9 & 53 & 100 & \\
\hline
\end{tabular}

Hasil uji statistik diperoleh nilai $p=0,002$ maka dapat disimpulkan bahwa ada hubungan yang bermakna antara kepercayaan dengan pemberian imunisasi dasar lengkap pada bayi.

Tabel 6
Hubungan Dukungan Suami dengan Pemberian Imunisasi Dasar Lengkap pada Bayi di Wilayah Kerja Puskesmas Pijorkoling

\begin{tabular}{|c|c|c|c|c|c|c|c|}
\hline \multirow{3}{*}{$\begin{array}{c}\text { Dukun } \\
\text { gan } \\
\text { Suami }\end{array}$} & \multicolumn{5}{|c|}{$\begin{array}{c}\text { Pemberian } \\
\text { Imunisasi Dasar Lengkap }\end{array}$} & \multirow{2}{*}{$\begin{array}{c}\text { Tota } \\
\quad 1\end{array}$} & \multirow{3}{*}{ Nilai $p$} \\
\hline & \multicolumn{2}{|c|}{ Lengkap } & \multicolumn{3}{|c|}{ Tidak Lengkap } & & \\
\hline & $\mathbf{N}$ & $\%$ & $\mathbf{N}$ & $\%$ & $\mathbf{N}$ & $\%$ & \\
\hline Baik & 15 & 55,6 & 12 & 44,4 & 27 & 100 & \\
\hline Kurang & 7 & 13,0 & 47 & 87,0 & 54 & 100 & 0,001 \\
\hline
\end{tabular}

Hasil uji statistik diperoleh nilai $p=0,001$ maka dapat disimpulkan bahwa ada hubungan yang bermakna antara dukungan suami dengan pemberian imunisasi dasar lengkap pada bayi.

Tabel 7

Hubungan Dukungan Tenaga Kesehatan dengan Pemberian Imunisasi Dasar Lengkap pada Bayi di Wilayah Kerja Puskesmas Pijorkoling

\begin{tabular}{cccccccc}
\hline \multirow{2}{*}{$\begin{array}{c}\text { Dukun } \\
\text { gan }\end{array}$} & \multicolumn{4}{c}{ Pemberian } & & \\
\cline { 2 - 6 } $\begin{array}{c}\text { Tenanisasi Dasar Lengkap } \\
\text { Keseha } \\
\text { tan }\end{array}$ & Lengkap & \multicolumn{3}{c}{ Tidak Lengkap } & & $\begin{array}{c}\text { Tilai } \\
p\end{array}$ \\
\cline { 2 - 6 } & $\mathrm{N}$ & $\%$ & $\mathrm{~N}$ & $\%$ & $\mathrm{~N}$ & $\%$ & \\
\hline Baik & 19 & 29,7 & 45 & 70,3 & 64 & 100 & 0,37 \\
Kurang & 3 & 17,6 & 14 & 82,4 & 17 & 100 & 7 \\
\hline
\end{tabular}

Hasil uji statistik diperoleh nilai $p=0,377$ maka dapat disimpulkan bahwa tidak ada hubungan antara dukungan tenaga kesehatan dengan pemberian imunisasi dasar lengkap pada bayi oleh ibu.

\section{PEMBAHASAN}

Pemberian imunisasi pada bayi dicatat dalam Kartu Menuju Sehat (KMS) yaitu jadwal dan jenisjenis imunisasi. KMS ini menjadi indikator peneliti untuk menentukan apakah ibu balita sudah memberikan imunisasi dasar lengkap atau tidak. Berdasarkan hasil penelitian menunjukkan dari 81 responden hanya 22 orang $(27,2 \%)$ yang memberikan imunisasi dasar lengkap pada bayinya dan sebanyak 59 orang $(72,8 \%)$ tidak memberikan imunisasi dasar lengkap pada bayinya.

Setelah dilakukan penelitian ternyata banyak ibu yang mempunyai bayi tidak memberikan imunisasi dasar lengkap pada bayinya, bahkan ada beberapa ibu balita tidak pernah memberikan imunisasi pada bayi dengan alasan kasihan kepada bayi masih kecil sudah disuntik, belum 40 hari sudah disuntik, mereka beranggapan bahwa imunisasi membuat anak menjadi sakit bukan bertambah sehat. Kebanyakan responden hanya memberikan imunisasi polio kepada bayi, sehingga ibu menganggap dengan satu jenis imunisasi 
sudah cukup untuk meningkatkan kekebalan tubuh pada bayi. Ada juga yang mengatakan tidak ada gunanya anak disuntik ataupun diberi obat imunisasi padahal anaknya dalam kondisi sehat. Menurut mereka menjadikan anak menjadi sehat bukan harus diberikan imunisasi, cukup diberikan makanan yang banyak dan minum susu.

Salah satu penyebab mereka tidak mau melakukan imunisasi karena efek samping bisa membuat anak sakit. Hal ini terjadi pada seorang responden yang mengatakan setelah anak pertamanya diimunisasi anaknya tidak bisa berjalan dengan baik. Kejadian ini membuat dia menjadi percaya bahwa imunisasi bisa mengakibatkan anak cacat.

Penelitian ini sejalan dengan penelitian yang dilakukan Silitonga di Kabupaten Tapanuli Utara dari 197 responden yang diteliti hanya 66 responden yang memberikan imunisasi dasar lengkap pada bayinya dan sebanyak 131 responden yang tidak memberikan imunisasi dasar lengkap pada bayinya dengan alasan anak sedang sakit, ibu sering menunda jadwal pemberian imunisasi, tidak sesuainya jadwal imunisasi dengan kegiatan-kegiatan ibu (ibu sibuk) dan lainlain. ${ }^{11}$

Pemberian imunisasi dasar lengkap sangat memengaruhi kesehatan bayi. Imunisasi merupakan suatu upaya untuk menimbulkan/meningkatkan kekebalan seseorang secara aktif terhadap suatu penyakit, sehingga bila suatu saat terpajan dengan penyakit tersebut tidak akan sakit atau hanya mengalami sakit ringan. ${ }^{13}$ Apabila anak diimunisasi lengkap maka ketahanan tubuh bayi akan meningkat dan tidak mudah tertular penyakit yang dapat dicegah dengan imunisasi. Anak dikatakan sudah mendapat imunisasi lengkap apabila anak sudah mendapat imunisasi satu kali BCG, tiga kali DPT-HB, empat kali polio dan satu kali campak sebelum anak berusia satu tahun. $^{7}$

Salah satu indikator menentukan status kesehatan suatu Negara adalah dengan melihat angka kematian balita atau derajat kesehatan anak mencerminkan derajat kesehatan bangsa, sebab anak sebagai generasi penerus memiliki kemampuan yang dapat dikembangkan. Pertumbuhan dan perkembangan anak di masa balita sangat dipengaruhi oleh perilaku ibu dalam mengurus anak terutama balita. Selain itu pertumbuhan dan perkembangan anak bisa dipengaruhi dari faktor lingkungan yang masih bisa diperbaiki. Misalnya pertumbuhan dan perkembangan anak bisa dilihat dari asupan nutrisi atau gazi pada balita dan pemberian imunisasi pada balita.
Pertumbuhan dan perkembangan anak diperlukan kebutuhan dasar anak yang harus terpenuhi yang dikenal dengan asuh, asah dan asih. Asuh berupa kebutuhan fisik-biomedis, asah bermakna kebutuhan latihan/rangsangan/stimulasi sedangkan asih bermakna kebutuhan kasih sayang/emosi. Kebutuhan asuh mencakup kebutuhan pangan/gizi, pemukiman yang layak, kebersihan lingkungan, pakaian, kesegaran jasmani dan yang tidak kalah penting yaitu imunisasi. Anak yang sehat akan tumbuh dan berkembang dengan baik sedangkan anak yang sering sakit akan terganggu pula tumbuh kembangnya. ${ }^{27}$

Kebutuhan dasar ini sangat penting dalam membantu pertumbuhan dan perkembangan anak. Kebutuhan akan imunisasi (memperoleh vaksin agar ter agai penyakit seperti campak, TBC, po tusis, tetanus). Sebagai kebutuhan da kapan imunisasi sangat penting bagi pe $\quad$ serkembangan anak. ${ }^{2}$

bahwa tujuan pemberian imunisasi pada anak yaitu diharapkan anak menjadi kebal terhadap penyakit sehingga dapat mengurangi kecacatan akibat penyakit yang dapat dicegah dengan imunisasi. Jadi, anak yang tidak diimunisasi akan meningkatkan morbilitas, mortalitas serta kecacatan pada anak. ${ }^{2}$ Oleh karena itu, anak yang cacat akan mengalami penghambatan pada pertumbuhan dan perkembangan anak. Pertumbuhan dan perkembangannya tidak akan sesuai dengan usianya.

Imunisasi merupakan bagian dari pemantauan kesehatan yang menjadi kebutuhan dasar anak untuk tumbuh kembang optimal. Imunisasi bukan hanya melindungi seseorang terhadap penyakit tertentu namun bisa menurunkan angka kejadian (prevalensi) penyakit dan salah satu cara untuk menurunkan angka kematian balita. Memberikan imunisasi secara lengkap kepada anak akan meningkatkan tumbuh kembangnya karena kesehatannya terpelihara dengan baik.

Hal yang terpenting yaitu ketelatenan si ibu dalam memberikan imunisasi dasar lengkap pada bayi, umur 0-5 tahun merupakan golden age (masa keemasan) bagi perkembangan otak atau keceradasan anak. Setiap bayi memiliki potensi miliyaran sel otak yang siap mendapat rangsangan. Seluruh sel ini punya peran penting dalam menunjang fungsi otak sebagai pengatur semua kemampuan anak di masa dewasa.

Berdasarkan hal tersebut pemberian imunisasi dasar lengkap pada bayi sangat erat hubungannya dengan pertumbuhan dan perkembangan anak, karena anak yang sehat akan tumbuh dan berkembang secara optimal. Hal ini sejalan dengan penelitian yang dilakukan Kaunang, dkk tentang hubungan pemberian 

Vol. 16 No. 3 September - Desember 2021

imunisasi dasar dengan tumbuh kembang pada bayi (01 tahun) di Puskesmas Kembes Kecamatan Tombulu Kabupaten Minahasa dengan hasil penelitian terdapat hubungan antara permberian imunisasi dasar lengkap terhadap pertumbuhan dan perkembangan bayi dengan nilai $p$ value $0,001 .^{28}$

Anak yang tidak diimunisasi akan rentan terhadap sakit seperti demam, batuk, pilek dan bisa terkena penyakit tertentu seperti TBC, difteri, pertusis, tetanus, polio, campak dan mudah tertular dari orang disekitarnya karena daya tahan tubuh menurun. Anak yang sakit akan berdampak pada asupan nutrisi atau menyebabkan nafsu makan berkurang sehingga asupan nutrisi tidak terpenuhi. Nutrisi merupakan salah satu komponen yang paling penting dalam menunjang keberlangsungan proses pertumbuhan dan perkembangan anak, tidak kalah pentingnya dengan pemberian imunisasi dasar lengkap pada bayi untuk pertumbuhan dan perkembangan anak. Oleh karena itu, seorang ibu harus berperilaku baik terhadap pemberian imunisasi dasar lengkap pada bayi agar meningkatkan kekebalan tubuh bayi, bayi akan terhindar dari penyakit menular tertentu, pertumbuhan dan perkembangan balita akan terjaga dan menurunkan angka kesakitan dan kematian pada bayi.

\section{KESIMPULAN}

Berdasarkan hasil penelitian diperoleh bahwa ada pengaruh faktor pemudah (pengetahuan dan kepercayaan) terhadap pemberian imunisasi dasar lengkap pada bayi di wilayah kerja Puskesmas Pijorkoling. Berdasarkan hasil penelitian diperoleh bahwa tidak ada pengaruh karakteristik ibu (pekerjaan dan paritas) faktor penguat (dukungan suami dan dukungan tenaga kesehatan) terhadap pemberian imunisasi dasar lengkap pada bayi di wilayah kerja Puskesmas Pijorkoling.

\section{DAFTAR PUSTAKA}

1. Rini, Susilo dan Kumala, Feti. Panduan Asuhan Hadinegoro, dkk. Pedoman imunisasi di Indonesia. Jakarta: Badan Penerbit Ikatan Dokter Anak Indonesia; 2011.

2. Hadinegoro, dkk, Panduan imunisasi anak mencegah lebih baik daripada mengobati. Jakarta: IDAI; 2014.

3. Kementerian Kesehatan RI. Permenkes nomor 42 tahun 2013 tentang penyelenggaraan imunisasi. Jakarta; 2013.

4. Kementerian Kesehatan Republik Indonesia. Profil Kesehaan Indonesia. Jakarta; 2014.
5. Kementerian Kesehatan Republik Indonesia. Riset kesehatan dasar. Jakarta; 2013.

6. Worang, dkk. Analisis faktor-faktor yang berhubungan dengan perilaku ibu dalam pemberian imunisasi dasar pada balita [e-journal]. 2014 [diunduh pada 10 September 2015]; 7. Tersedia dari: ejournal.unsrat.ac.id

7. Silitonga M. Pengaruh faktor pemudah, pemungkin dan penguat terhadap pemberian imunisasi dasar lengkap pada bayi. [Tesis]. Medan: Universitas Sumatera Utara; 2012.

8. Notoatmodjo S. Metodologi penelitian kesehatan, Jakarta: Rineka Cipta; 2010.

9. Kaunang, dkk. Hubungan pemberian imunisasi dasar dengan tumbuh kembang pada bayi (0-1 tahun) di Puskesmas Tombulu Kabupaten Minahasa [e-journal]. 2016 [diunduh 02 Februari 2016]; 4 (1): 231. Tersedia dari: ejournal.unsrat.ac.id 